\title{
Erratum \\ Erratum: Torra et al. Amaranthus palmeri a New Invasive Weed in Spain with Herbicide Resistant Biotypes. Agronomy 2020, 10, 993
}

\author{
Joel Torra $^{1, *(\mathbb{D}}$, Aritz Royo-Esnal ${ }^{1} \mathbb{D}$, Yolanda Romano ${ }^{2}$, María Dolores Osuna ${ }^{2} \mathbb{D}$, Ramón G. León ${ }^{3} \mathbb{D}$ \\ and Jordi Recasens ${ }^{1}$ (D) \\ 1 Departament d'Hortofructicultura, Botànica i Jardineria, Agrotecnio, Universitat de Lleida, \\ 25198 Lleida, Spain; aritz.royo@udl.cat (A.R.-E.); jordi.recasens@udl.cat (J.R.) \\ 2 Agrarian Research Center 'Finca La Orden' Valdesequera, 06187 Badajoz, Spain; yigui76@hotmail.com (Y.R.); \\ mdosuna@gmail.com (M.D.O.) \\ 3 Department of Crop and Soil Sciences, North Carolina State University, Raleigh, NC 27695-7620, USA; \\ rleon@ncsu.edu \\ * Correspondence: joel.torra@udl.cat; Tel.: +34-973-702318
}

check for updates

Citation: Torra, J.; Royo-Esnal, A.; Romano, Y.; Osuna, M.D.; León, R.G.; Recasens, J. Erratum: Torra et al. Amaranthus palmeri a New Invasive Weed in Spain with Herbicide Resistant Biotypes. Agronomy 2020, 10, 993. Agronomy 2021, 11, 1332. https://doi.org/10.3390/ agronomy 11071332

Received: 7 June 2021 Accepted: 23 June 2021 Published: 30 June 2021

Publisher's Note: MDPI stays neutral with regard to jurisdictional claims in published maps and institutional affiliations.

Copyright: (c) 2021 by the authors. Licensee MDPI, Basel, Switzerland. This article is an open access article distributed under the terms and conditions of the Creative Commons Attribution (CC BY) license (https:// creativecommons.org/licenses/by/ $4.0 /)$.
The authors would like to make the following correction to the published paper [1]:

Revise the content in Section 2.4 from "All mutations conferring ALS resistance in $A$. palmeri in positions Ser653, Trp574, Pro197, Pro197, Ala122 and Ala122 of CAD and BE domains" to "All mutations conferring ALS resistance in A. palmeri in positions Gly654, Ser653, Trp574, Ala205, Pro197 and Ala122 of CAD and BE domains". Mutations were found in positions Ser653, Trp574 and Pro197.

The authors and Agronomy Editorial Office would like to apologize for any inconvenience caused to the readers by these changes. The changes do not affect the scientific results. The published version will be updated on the article's webpage, with a reference to this erratum.

Conflicts of Interest: The authors declare no conflict of interest. The funders had no role in the design of the study; in the collection, analyses or interpretation of data; in the writing of the manuscript or in the decision to publish the results.

\section{Reference}

1. Torra, J.; Royo-Esnal, A.; Romano, Y.; Osuna, M.D.; León, R.G.; Recasens, J. Amaranthus palmeri a New Invasive Weed in Spain with Herbicide Resistant Biotypes. Agronomy 2020, 10, 993. [CrossRef] 